\title{
Effect of Sr Substitution for RE on Microstructure and Tensile Properties in Mg-Al-RE Casting Alloys
}

\author{
Joong-Hwan Jun ${ }^{\dagger}$ \\ Advanced Fusion Process R\&D Group, Korea Institute of Industrial Technology, Incheon 406-840, Korea
}

\begin{abstract}
본 연구는 $\mathrm{Mg}-\mathrm{Al}$ 합금에 첨가된 희토류 금속(rare earth metal, RE)과 스트론튬( $\mathrm{Sr}$ )이 상온 및 고온 기계적 특성에 미치는 영향을 비교하고, 그 결과를 미세조직의 변화와 연관지어 분석하는 것이 목적이다. 이를 위해 4 종의 $\mathrm{Mg}-6 \% \mathrm{Al}-(3-\mathrm{X}) \% \mathrm{RE}-$ $\mathrm{X} \% \mathrm{Sr}$ 합금 $(\mathrm{X}=0 \sim 3)$ 을 마련하여 $\mathrm{RE}$ 를 $\mathrm{Sr}$ 으로 대체하면서 상온 및 고온 인장 특성, 크립 저항성을 평가하였다. $\mathrm{RE}$ 가 $\mathrm{Sr}$ 으 로 대체 됨에 따라, 층상구조의 $\left(\alpha+\mathrm{Al}_{4} \mathrm{Sr}\right)$ 상이 $\alpha$ 덴드라이트 사이에 생성되면서 침상의 $\mathrm{Al}_{4} \mathrm{RE}$ 상이 점차 소멸하였으며 $\mathrm{Mg}$ $6 \% \mathrm{Al}-3 \% \mathrm{Sr}$ 합금에서는 $\left(\alpha+\mathrm{Al}_{4} \mathrm{Sr}\right)$ 과 블록형 태의 $\mathrm{Mg}-\mathrm{Al}-\mathrm{Sr}$ 상이 관찰되었다. $\mathrm{Sr}$ 함량이 증가할수록 항복강도와 크립저항성 은 지속적으로 향상되는 경향을 나타내었다.
\end{abstract}

Key words : Mg-Al-RE alloy, Sr, Tensile properties, Creep resistance.

(Received August 22, 2011 ; Accepted September 26, 2011)

\section{Introduction}

Magnesium $(\mathrm{Mg})$ and its alloys have gained an increasing attention due to their low density $\left(\sim 1.8 \mathrm{~g} / \mathrm{cm}^{3}\right)$, high specific solidity, good machinability and damping capacity [1-2]. However, relatively inferior tensile strength and creep resistance of $\mathrm{Mg}$ alloys at elevated temperatures in comparison with competitive $\mathrm{Al}$ alloys, have limited their further utilization as weight-saving structural material in automotive and aerospace applications. Consequently, principal researches for widespread use of the $\mathrm{Mg}$ alloys have focused on the improvement in mechanical properties at elevated temperatures [3-6].

It is well established that rare earth metals (RE) and Strontium (Sr) are very beneficial in improving high temperature strength and creep resistance of the $\mathrm{Mg}$ alloys by an introduction of Al-RE, Al-Sr and/or Mg-Al-Sr compounds possessing high thermal stabilities [7-9]. In spite of numerous works on RE and/or Sr-containing Mg-Al based alloys [7-12], however, efficiencies of RE and $\mathrm{Sr}$ elements in mechanical properties at room and elevated temperatures have not been comparatively investigated. In this study, we report on the changes in microstructures and tensile properties at room and elevated temperatures with $\mathrm{Sr}$ content in Mg-6\%Al-(3$\mathrm{X}) \% \mathrm{RE}-\mathrm{X} \% \mathrm{Sr}(\mathrm{X}=0 \sim 3)$ permanent mold casting alloys.

\section{Experimental}

Four Mg-6\%Al based alloys containing 3\%RE, 2\%RE-
$1 \% \mathrm{Sr}, 1 \% \mathrm{RE}-2 \% \mathrm{Sr}$ and $3 \% \mathrm{Sr}$ (in weight), respectively, were prepared by melting $99.9 \% \mathrm{Mg}, 99.9 \% \mathrm{Al}, 99.0 \% \mathrm{RE}$ (Ce-rich misch metal, $\sim 55 \%$ of $\mathrm{Ce}, \sim 22 \%$ of $\mathrm{La}, \sim 18 \%$ of $\mathrm{Nd}$ and $\sim 5 \%$ of $\mathrm{Pr}$ ) and $99.0 \% \mathrm{Sr}$ under a $\left(\mathrm{SF}_{6}+\mathrm{CO}_{2}\right)$ covering gas and casting into a metallic mould. From the ingots, various specimens for optical microscopy (OM), scanning electron microscopy (SEM), X-ray diffractometry (XRD), tensile and creep tests were prepared by machining. Chemical compositions of experimental alloys determined by means of ICP, are listed in Table 1.

Tensile tests were conducted at room temperature and $175^{\circ} \mathrm{C}$ with a constant initial strain rate of $6.7 \times 10^{-4} \mathrm{~s}^{-1}$ with an Instron-type tensile testing machine. ASTM subsize specimens with a gauge length of $25 \mathrm{~mm}$ were employed. Tensile creep tests were also performed on $100 \mathrm{MPa}$ at $175^{\circ} \mathrm{C}$. Microstructural examinations were carried out by means of XRD (Rigaku CN2200) with $\mathrm{Cu}-\mathrm{K} \alpha$ radiation, OM (Olympus CK-40M) and SEM (FEI Sirion FESEM) equipped with energy dispersive X-ray spectrometer (EDAX) system. Samples for OM and SEM observations were mechanically polished and chemically

Table 1. Chemical compositions of experimental alloys (in weight).

\begin{tabular}{|c|c|c|c|c|c|}
\hline & Composition & $\mathrm{Al}$ & $\mathrm{RE}$ & $\mathrm{Sr}$ & $\mathrm{Mg}$ \\
\hline 1 & Mg-6\%Al-3\%RE & 5.87 & 2.64 & - & Bal. \\
\hline 2 & $\mathrm{Mg}-6 \% \mathrm{Al}-2 \% \mathrm{RE}-1 \% \mathrm{Sr}$ & 5.94 & 1.88 & 0.86 & Bal. \\
\hline 3 & Mg-6\%Al-1\%RE-2\%Sr & 6.09 & 1.10 & 1.81 & Bal. \\
\hline 4 & $\mathrm{Mg}-6 \% \mathrm{Al}-3 \% \mathrm{Sr}$ & 5.72 & - & 2.71 & Bal. \\
\hline
\end{tabular}

${ }^{\dagger}$ E-mail : jhjun@kitech.re.kr 
etched with a solution of $5 \mathrm{~mL}$ acetic acid $+6 \mathrm{~g}$ picric acid + $10 \mathrm{~mL} \mathrm{H} \mathrm{H}_{2} \mathrm{O}+100 \mathrm{~mL}$ ethanol.

\section{Results and Discussion}

\subsection{Microstructures}

Optical microstructures for $\mathrm{Mg}-6 \% \mathrm{Al}-(3-\mathrm{X}) \% \mathrm{RE}-\mathrm{X} \% \mathrm{Sr}$ alloys are represented in Fig. 1. As reported in a previous work [10], the microstructure of $\mathrm{Mg}-6 \% \mathrm{Al}-3 \% \mathrm{RE}$ alloy is distinctively characterized by random distribution of clusters of needle-like $\mathrm{Al}_{4} \mathrm{RE}$ intermetallic compounds within $\alpha(\mathrm{Mg})$ grains and small amount of $\beta\left(\mathrm{Mg}_{17} \mathrm{Al}_{12}\right)$ phase with fine particular morphology. It is well known that the Mg-Al binary alloy shows inferior high temperature strength and creep resistance because the $\beta$ phase with $437^{\circ} \mathrm{C}$ of low melting temperature is easily softened and coarsened at elevated temperature above $120^{\circ} \mathrm{C}$ [13]. Dominance of $\mathrm{Al}_{4} \mathrm{RE}$ compounds in the $\mathrm{Mg}-6 \% \mathrm{Al}-3 \% \mathrm{RE}$ alloy (Fig. 1(a)) may well be attributed to the higher chemical interaction of $\mathrm{Al}$ and $\mathrm{RE}$ elements and higher forming temperature of $\mathrm{Al}_{4} \mathrm{RE}$ than $\beta$ phase, which results in the early consumption of $\mathrm{Al}$ atoms before formation of $\beta$ phase during solidification. It is noted in Fig. 1 that with increasing $\mathrm{Sr}$ content, dendritic morphology of $\alpha$ grains becomes obvious and the amount of eutectic phase at the interdendritic region increases gradually.

Secondary electron images for the Mg-6\%Al-(3-X)\%RE-

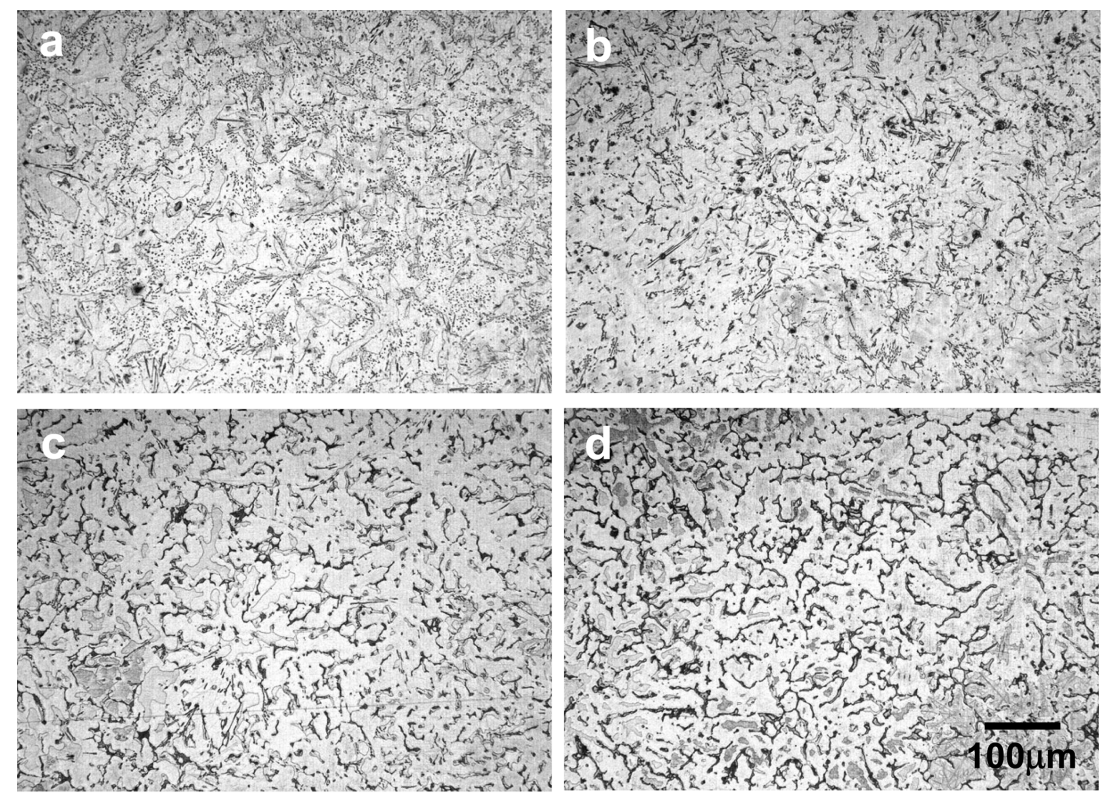

Fig. 1. Optical microstructures of Mg-6\%Al-(3-X)\%RE-X\%Sr alloys : (a) Mg-6\%Al-3\%RE, (b) Mg-6\%Al-2\%RE-1\%Sr, (c) Mg-6\%Al-1\%RE$2 \% \mathrm{Sr}$ and (d) $\mathrm{Mg}-6 \% \mathrm{Al}-3 \% \mathrm{Sr}$.
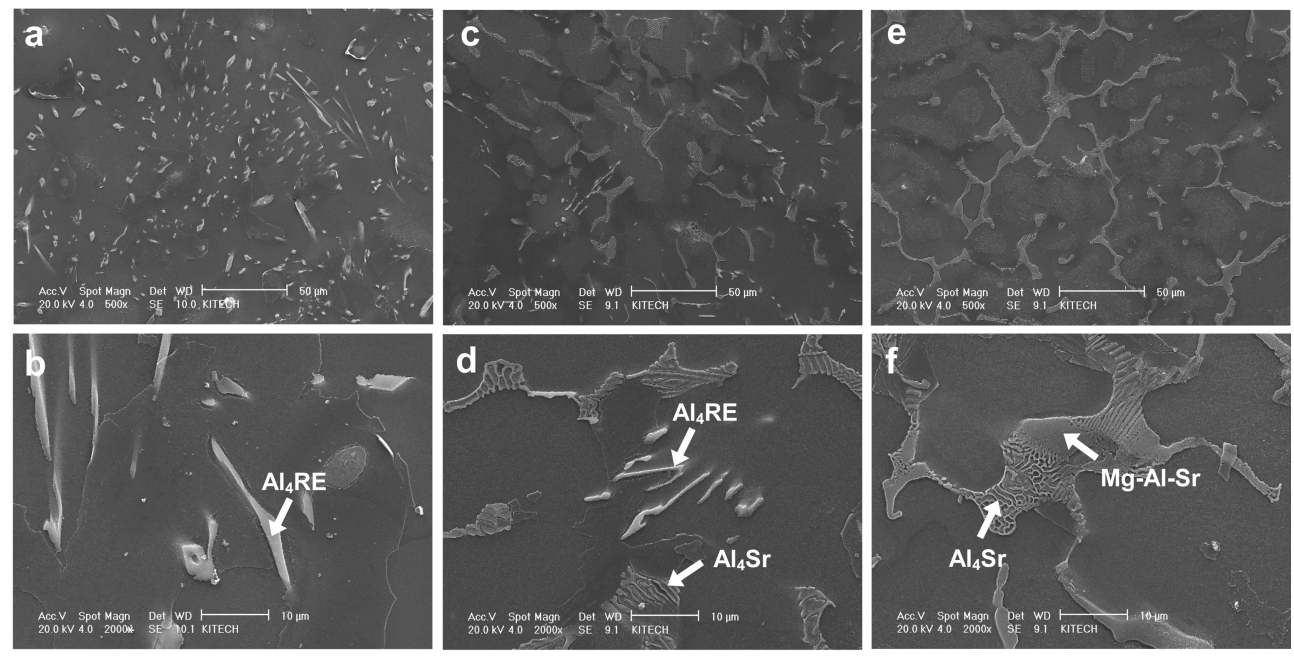

Fig. 2. Secondary electron images of Mg-6\%Al-(3-X)\%RE-X\%Sr alloys : (a), (b) Mg-6\%Al-3\%RE, (c), (d) Mg-6\%Al-1\%RE-2\%Sr and (e), (f) $\mathrm{Mg}-6 \% \mathrm{Al}-3 \% \mathrm{Sr}$. 
$\mathrm{X} \% \mathrm{Sr}$ alloys are given in Fig. 2. Fig. 2(a) and (b) clearly represents the various sizes of needle-shaped $\mathrm{Al}_{4} \mathrm{RE}$ phase within the grains. By the substitution of Sr for RE, eutectic $\mathrm{Al}_{4} \mathrm{Sr}$ precipitates with lamellar morphology are formed in the interdendritic regions. The $\mathrm{Al}_{4} \mathrm{RE}$ is still visible, but its volume fraction and size become reduced as observed in the $\mathrm{Mg}-6 \% \mathrm{Al}-$ 1\%RE-2\%Sr alloy (Fig. 2(c) and (d)). The Mg-6\%Al-3\%Sr alloy shows dendritic grains and interdendritic eutectic phases consisting of bulky compounds and lamellar $\mathrm{Al}_{4} \mathrm{Sr}$ phase with more continuous manner (Fig. 3(e) and (f)). EDS analyses revealed that bulky phase is $\mathrm{Mg}_{13} \mathrm{Al}_{3} \mathrm{Sr}$ ternary compound as reported by Jing et al. [8]. In a previous study [14], it has been reported that the type of Sr-related compound in the Mg-Al-Sr based alloys depends on the ratio of $\mathrm{Sr} / \mathrm{Al}$ concentrations. When the $\mathrm{Sr} / \mathrm{Al}$ ratio in the alloy is lower than 0.3 , only $\mathrm{Al}_{4} \mathrm{Sr}$ can form in the microstructure while the $\mathrm{Sr} / \mathrm{Al}$ ratio is higher than 0.3 , the Mg-Al-Sr ternary phase will appear besides $\mathrm{Al}_{4} \mathrm{Sr}$ phase. Thus, the existence of Mg-Al-Sr ternary phase in the $\mathrm{Mg}-6 \% \mathrm{Al}-3 \% \mathrm{Sr}$ alloy with $\mathrm{Sr} / \mathrm{Al}$ ratio of 0.5 is well consistent with the previous results.

XRD patterns in the Mg-6\%Al-(3-X)\%RE-X\%Sr alloys are shown in Fig. 3. Several peaks corresponding to $\alpha, \mathrm{Al}_{4} \mathrm{Ce}$ and $\beta$ phases appear in the Mg- $6 \% \mathrm{Al}-3 \% \mathrm{RE}$ alloy, demonstrating that this alloy contains small amount of $\beta$ phase in combination with $\alpha$ and $\mathrm{Al}_{4} \mathrm{RE}$ as seen in the optical and SEM microstructures (Fig. 1(a), Fig. 2(a), (b)). With the increase in $\mathrm{Sr}$ content, $\mathrm{Al}_{4} \mathrm{Sr}$ peaks are additionally introduced whereas the $\mathrm{Al}_{4} \mathrm{Ce}$ peaks become gradually decayed due to the decreased $\mathrm{RE}$ content. It is noted that the $\beta$ peaks are not visible in the Sr-containing alloys.

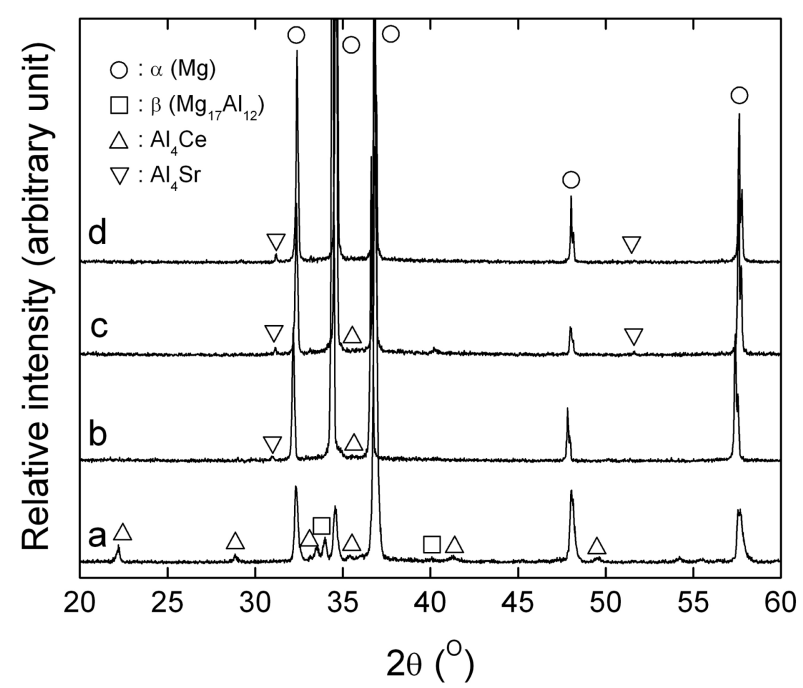

Fig. 3. XRD patterns of Mg-6\%Al-(3-X)\%RE-X\%Sr alloys : (a) $\mathrm{Mg}-6 \% \mathrm{Al}-3 \% \mathrm{RE}$, (b) Mg-6\%Al-2\%RE-1\%Sr, (c) Mg-6\%Al$1 \% \mathrm{RE}-2 \% \mathrm{Sr}$ and (d) $\mathrm{Mg}-6 \% \mathrm{Al}-3 \% \mathrm{Sr}$.

\subsection{Tensile properties}

Fig. 4 represents the changes in yield strength (YS), ultimate tensile strength (UTS) and elongation at RT and $175^{\circ} \mathrm{C}$ with $\mathrm{Sr}$ content in the Mg-6\%Al-(3-X)\%RE-X\%Sr alloys. At RT, YS increases continuously with increasing $\mathrm{Sr}$ content, whereas UTS and elongation to failure become lower. At $175^{\circ} \mathrm{C}$, however, YS and UTS are improved simultaneously in the alloys with higher amounts of $\mathrm{Sr}$, even though the elongation is still deteriorated slightly.

Creep curves and minimum creep rates of the $\mathrm{Mg}-6 \% \mathrm{Al}-(3-$ $\mathrm{X}) \% \mathrm{RE}-\mathrm{X} \% \mathrm{Sr}$ alloys tested at $175^{\circ} \mathrm{C}$ under $100 \mathrm{MPa}$ are given in Figs. 5 and 6, respectively. The Sr substitution for RE leads to the abrupt decrease in minimum creep rates from $14.49 \times 10^{-4}$ $\mathrm{s}^{-1}$ (Mg-6\%Al-3\%RE) to $0.27 \times 10^{-4} \mathrm{~s}^{-1}$ (Mg-6\%Al-3\%Sr). The $\sim 50$ times lower minimum creep rate of the $\mathrm{Mg}-6 \% \mathrm{Al}-3 \% \mathrm{Sr}$ alloy than the $\mathrm{Mg}-6 \% \mathrm{Al}-3 \% \mathrm{RE}$ alloy indicates that $\mathrm{Sr}$ is more beneficial in creep resistance of the Mg-Al based alloys than RE. After considering that the principal strengthening phases of $\mathrm{Al}_{4} \mathrm{RE}$ and $\mathrm{Al}_{4} \mathrm{Sr}$ would possess practically same level of thermal stability resulting from their similar melting temperatures over $1000^{\circ} \mathrm{C}$ [14], the improvement in tensile strength and
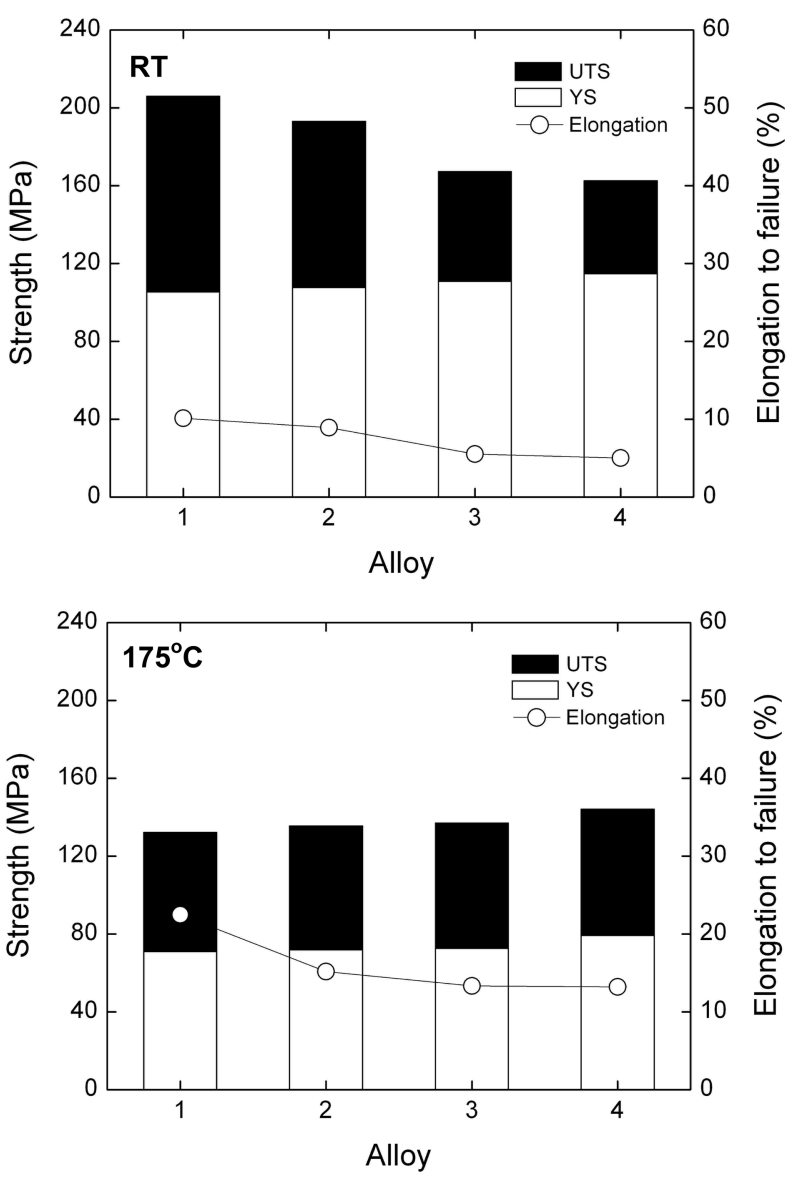

Fig. 4. Tensile properties at RT and $175^{\circ} \mathrm{C}$ for $\mathrm{Mg}-6 \% \mathrm{Al}-(3-\mathrm{X}) \% \mathrm{RE}-$ $\mathrm{X} \% \mathrm{Sr}$ alloys. 


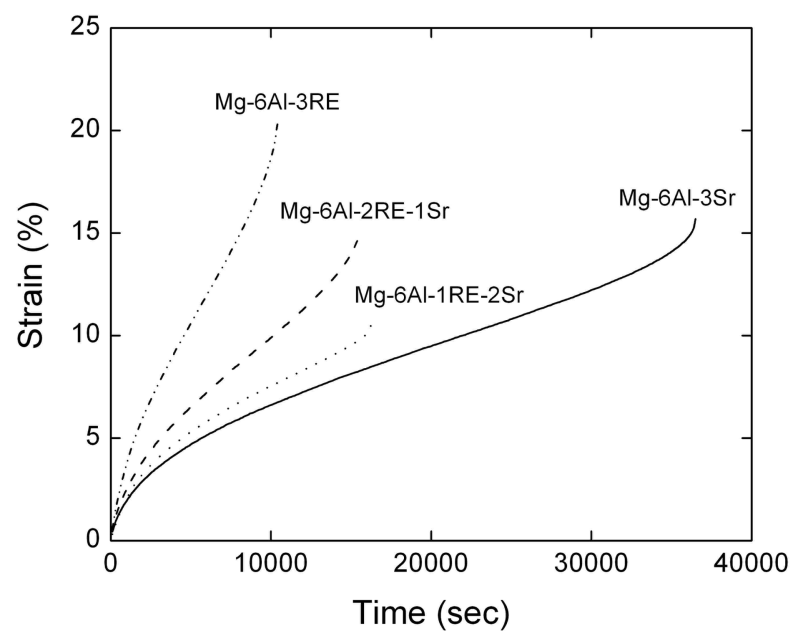

Fig. 5. Creep curves of Mg-6\%Al-(3-X)\%RE-X\%Sr alloys obtained at $175^{\circ} \mathrm{C}$ under $100 \mathrm{MPa}$.

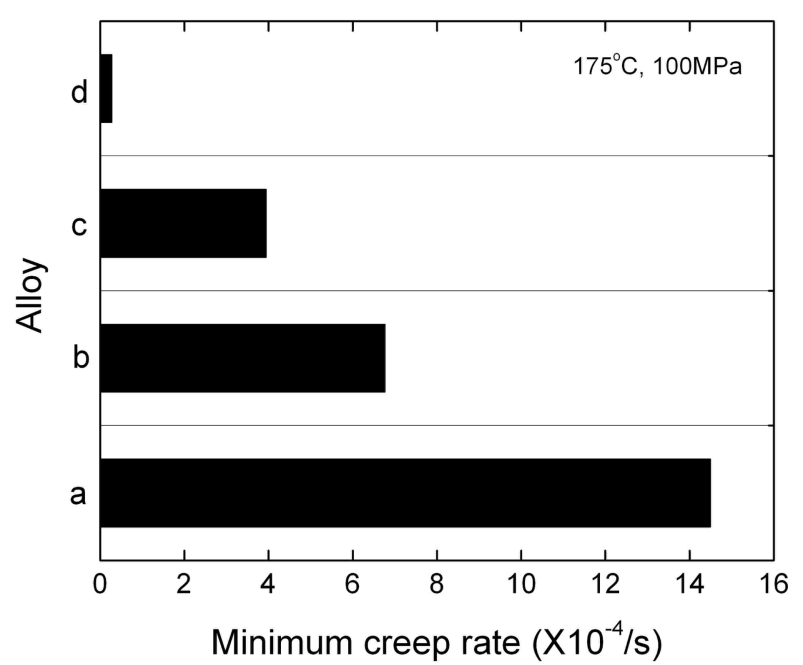

Fig. 6. Comparison of minimum creep rates for $\mathrm{Mg}-6 \% \mathrm{Al}-(3-\mathrm{X})$ $\%$ RE-X\%Sr alloys measured at $175^{\circ} \mathrm{C}$ under $100 \mathrm{MPa}:$ (a) Mg-6\%Al-3\%RE, (b) Mg-6\%Al-2\%RE-1\%Sr, (c) Mg-6\%Al$1 \% \mathrm{RE}-2 \% \mathrm{Sr}$ and (d) $\mathrm{Mg}-6 \% \mathrm{Al}-3 \% \mathrm{Sr}$.

creep resistance by substituting RE with Sr may well be related to the formation of interdendritic eutectic structure consisting of $\mathrm{Al}_{4} \mathrm{Sr}$ and $\mathrm{Mg}-\mathrm{Al}-\mathrm{Sr}$ intermetallics. The higher the $\mathrm{Sr}$ content, volume fraction and continuity of the interdendritic phases become increased, yielding grain boundary strengthening and restricting grain boundary migration effectively during creep test.

\section{Summary}

Microstructures and tensile properties at ambient and elevated temperatures were studied by substituting $\mathrm{RE}$ for $\mathrm{Sr}$ in $\mathrm{Mg}$ $6 \% \mathrm{Al}-(3-\mathrm{X}) \% \mathrm{RE}-\mathrm{X} \% \mathrm{Sr}$ alloys $(\mathrm{X}=0 \sim 3)$. With increasing $\mathrm{Sr}$ content, $\mathrm{Al}_{4} \mathrm{Sr}$ phase with lamellar morphology was newly introduced at interdendritic regions, with a gradual extinction of needle-shaped $\mathrm{Al}_{4} \mathrm{RE}$. The $\mathrm{Mg}-6 \% \mathrm{Al}-3 \% \mathrm{Sr}$ alloy shows dendritic grains and interdendritic eutectic phases containing bulky $\mathrm{Mg}-\mathrm{Al}-\mathrm{Sr}$ and lamellar $\mathrm{Al}_{4} \mathrm{Sr}$ with more continuous manner. The substitution of $\mathrm{Sr}$ for RE provided higher YS, UTS and creep resistance at $175^{\circ} \mathrm{C}$, which indicates that $\mathrm{Sr}$ would be more beneficial in tensile properties and creep resistance at elevated temperature than $\mathrm{RE}$ for the $\mathrm{Mg}-\mathrm{Al}$ based casting alloys.

\section{References}

[1] B. L. Mordike and T. Ebert : Mater. Sci. Eng. A, "Magnesium: Properties-applications-potential", 302 (2001) 37-45

[2] H. Friedrich and S. Schumann: J. Mater. Proc. Tech., "Research for a "new age of magnesium" in the automotive industry", 117 (2001) 276-281

[3] A. Luo : Int. Mater. Rev., "Recent magnesium alloy development for elevated temperature applications", 49 (2004) 13-30

[4] B. L. Mordike : Mater. Sci. Eng. A, "Creep-resistant magnesium alloys", 324 (2002) 103-112

[5] A. Srinivasan, J. Swaminathan, M. K. Gunjan, U. T. S. Pillai and B. C. Pai : Mater. Sci. Eng. A, "Effect of intermetallic phases on the creep behavior of AZ91 magnesium alloy", 527 (2010) 1395-1403

[6] M. O. Pekguleryuz and A. A. Kaya : Adv. Eng. Mater., "Creep resistant magnesium alloys for powertrain applications", 5 (2003) 866-878

[7] F. Khomamizadeh, B. Nami and S. Khoshkhooei : Metall. Mater. Trans. A, "Effect of rare-earth element additions on high temperature mechanical properties of AZ91 magnesium alloy", 36 (2005) 3489-3494

[8] B. Jing, S. Yangshan, X. Shan, X. Feng and Z. Tianbai : Mater. Sci. Eng. A, "Microstructure and tensile creep behavior of Mg4Al based magnesium alloys with alkaline-earth elements $\mathrm{Sr}$ and Ca additions", 419 (2006) 181-188

[9] M. Kunst, A. Fischersworring-Bunk, G. L'esperance, P. Plamondon and U. Glatzel : Mater. Sci. Eng. A, "Microstructure and dislocation analysis after creep deformation of die-cast MgAl-Sr (AJ) alloy", 510-511 (2009) 387-392

[10] Y. Lu, Q. Wang, X. Zeng, W. Ding, C. Zhai and Y. Zhu : Mater. Sci. Eng. A, "Effects of rare earths on the microstructure, properties and fracture behavior of Mg-Al alloys", 278 (1999) 66-76

[11] S. M. Zhu, M. A. Gibson, J. F. Nie, M. A. Easton and T. B. Abbott : Scripta Mater., "Microstructural analysis of the creep resistance of die-cast Mg-4Al-2RE alloy", 58 (2008) 477-480

[12] T. Sato and M. V. Kral " Mater. Sci. Eng. A, "Microstructural evolution of Mg-Al-Ca-Sr alloy during creep”, 298 (2008) 369376

[13] G. Pettersen, H. Westengen, R. Hoier and O. Lohne : Mater. Sci. Eng. A, "Microstructure of a pressure die cast magnesium4wt.\% aluminum alloy modified with rare earth additions", 207 (1996) $115-120$

[14] H. Okamoto : ASM International, Phase Diagrams for Binary Alloys, (2000) 28

[15] H. Okamoto : ASM International, Phase Diagrams for Binary Alloys, (2000) 44 